\title{
Perceiving the Migrant as "Other": Analysis of Three Main Categories in the European Migration Context
}

\section{Abstract}

The article rethinks the contemporary approach to the process of othering, which observes it through the lenses of modern social changes. The general premise of the article is that othering can be analyzed in the context of migration to Europe through three main categories. Namely, the behavioral-perceptive category, symbolic category, and lingual category. By analyzing the relevant research and theories, I will attempt to show that migrants are always necessarily othered by the dominant population, but with specific differences between migrant groups - in terms of religion, language, culture, values, and race $!^{[1]}$

Keywords: the process of othering, migration, domicile society, discrimination

\section{Introduction}

Othering, a complex theory developed and analyzed by many theorists such as Jacques Lacan, Edward Said, Emmanuel Levinas, Simmel, and Michel de Certeau, is most briefly explained as the relationship of power and subordination during the encounter of different cultures (Said 5), groups, or individuals. The othering represents a ubiquitous process that we can follow from ancient history until today. It often forms the basis of social, international, or cross-cultural relations and can be seen as a trigger of behavior, creating a perception of others and identification with a specific group, as opposed to others. The Other represents a "stranger" that is at the same time geographically near but culturally far away, as Simmel explained in the context of the sociological theory (144). Although the evidence for the process of othering can be found in the entire history of 
human civilization, wars, and subordination of all kinds, it is also possible to recognize it in the interactions between different groups in the society (Kastoryano 79-80).

In modern, mostly western societies, we no longer necessarily analyze the concept of othering through colonization, conquest, or war, but through more subtle forms present in everyday life, such as interactions and behaviors of different groups or individuals in society. Since the dynamics of societies changes over the years, the analysis of the process of othering should follow the constantly changing social processes. Therefore, othering can be recognized in several levels of social change. The first level of social change where we can detect othering can be found in the subtle form of everyday interaction, events, actions, or even identity changes of an individual or a group (Kastoryano 83-85). The second level of social change can be found in the regional changes, such as war, confrontation, or other forms of social dynamics in a specific country where one ethnic or religious group is being othered (Kastoryano 86). The latter implies the global level, where we can analyze migration processes as the consequences of social changes, especially the last migration crisis with its peak in 2015. Therefore, in this paper, I will argue that the question of othering in the abovementioned socially dynamic process of migration in Europe is a fertile ground for this phenomenon since it resulted in the contact of different cultures and groups. Based on the existing research data and theory, I will attempt to show that othering can be analyzed in the context of migration through the following categories: behavioral-perceptive, symbolic, and lingual. The first category has to do with the contact of two or more different cultures, the first impulse of interaction that could lead to the othering process. The second category is analyzed to emphasize the important role of the symbolic dimension of several familiar concepts in societies, such as place or territory, media pictures, and boundaries that (sometimes) indirectly generate othering. Finally, the lingual category is an integral part of this analysis since the power of terminology used in the media often crosses the boundaries of media, becoming mainstream in everyday life and social interactions. Additionally, by following numerous research and theories, this paper will analyze the migrant individual as necessarily always othered by the dominant population, but with the specific differences between migrant groups in terms of religion, language, culture, values, and even race. 


\section{Behavior and Perception: The Elements of Othering in the Contact of Different Cultures}

In the analysis of behavior and social practices in the migration process, it is possible to observe two basic approaches to the migrant reception - securitarian and humanitarian (Pozniak and Petrović 48). The humanitarian approach refers to the assistance at the beginning of one's immigration to another country in terms of providing the secure accommodation that should be followed by the long-term integration process in the future.

Although the relation of the humanitarian approach to the othering might, at first, seem like a paradoxical one, this certainly does not mean that the othering cannot be recognized as a result of this approach. The humanitarian approach also carries the subtle traps of othering, though not as directly as a securitarian approach. The main aim of the securitarian approach is to preserve the borders of the country and protect the domicile population and culture from foreign nationals (Toğral Koca 55-56). Therefore, I argue the securitization on the middle level, in the contrast to individual and system level. According to the Copenhagen School securitization scale, the middle level of securitization lies on the political, group, or state securitization against another group or country; at the individual level, securitization takes human beings in general as the referent object, and finally, at the system level, securitization focuses on all the humankind (Buzan and Wæver 254). In the social practices of the middle level of securitization, certain elements of othering, which the domicile society directs toward the migrant population, can be observed through practices, behaviors, and participation in the major social institutions, such as education and healthcare, labor market, and democratic practices (voting, citizen participation, etc.) (Gregurović et al. 2). What makes the securitarian approach especially interesting is its direct assumption of perceiving migrants ${ }^{[2]}$ as others.

Within the securitarian approach, the emergence of the idea of othering can be observed through the examples of several European countries' socio-political reactions to numerically significant migration trends over the years, including the last migration that has started in 2014 and has since brought inevitable changes to European social dynamics. Therefore, my argumentation in this 
chapter begins with historical foundations, continues with empirical data, and rounds it with the theory of xenophobia and racism.

After World War Two, Europe was facing a lack of labor force. Part of the solution was to recruit permanent workers from abroad, but it was not until the end of the 1960s that it became clear immigration would be permanent (Zlatković Winter 161-62). Europeans dominantly perceived the migrants through the category of cheap labor force (Zlatković Winter 162). The securitarian approach was mainly focused on the strict control of migration processes, without any clear strategy for integration (Mesić 122-25). During those years, many people from Morocco, Algeria, Tunisia, Yugoslavia, and Turkey migrated to European countries. One of the conditions to reach Europe was to leave their families behind in their country of origin. During that period, migrant communities, which were perceived as communities of cheap labor workers, started to form. These communities have often been situated on the very margin of the city, isolated from other citizens. As a result, migrants seldom came in contact with the rest of the society, even though they might have lived in a European country for years (Zlatković Winter 162). Even in this period, the analysis of attitude toward foreign nationals in Europe was possible, as the fact that individuals were perceived dominantly in the context of cheap labor, and denied some of their rights, speaks of the clear division between "Europeans" on the one hand, and "Them" - migrants, others, newcomers, foreigners - on the other. Furthermore, during the 1990s, there was another sudden migration increase, and Europe, once again, turned to a securitarian approach. There were two main categories of migrants. The first category included refugees that the war had forced to emigrate from the former Yugoslavia, and the second category included legal and illegal migrants coming from Eastern Europe, the former USSR, and developing countries (Zlatković Winter 164). During that period, Europe introduced stricter supervision and control over the migrant population. According to Castles et al., Europe responded to the increasing number of migrants by introducing restrictive policies, including stricter border controls, refusing refugee status, and introducing a stricter legal framework in general (98). When it comes to the current migration context in Europe, it is possible to observe the presence of a securitarian approach in migrant reception centers, starting with Croatia. At the reception center for asylum seekers Porin in Zagreb, direct security measures have been implemented, as indicated by the type of shelter itself that is similar to a 
detention facility, which the center should not be in practice. It also implemented various control techniques, from checking the asylum seekers ${ }^{[3]}$ mobile devices, searching their rooms, to introducing the rule on reporting their entry and exit, as well as a limiting time to return to the shelter. The securitarian approach that has been observed in behaviors toward asylum seekers in Croatia from the very beginning of 2015 , indicates the preventive criminalization of migrants, as opposed to the need for complete integration into society (Pozniak and Petrović 49-50). This strategy implies the othering of the migrant population through actions that indicate their possible criminal predisposition and differentiation from the rest of the domicile society that in this dichotomy represents "peaceful citizens of the country" (Pozniak and Petrović 66). Such behavior examples, whether strategically justified or not, indicate elements of othering. According to Grubiša, who conducted a media representation review and the participant observation approach while volunteering during the short period of the refugee crisis,

We as the citizens of the European Union, represent the "developed" part of the world, the powerful West and "civilization values," whereas, on the scale of "development," we have placed refugees and migrants, the "Others," somewhere far below. In this regard, They are presented as "primitive" people from an "undeveloped" part of the world, people who have "strange" and "different" values and customs, and are thus a "threat" to the presumed "European" culture and way of life. (156)

After reviewing some of the important elements of othering present in the mentioned social practices, we can ask whether the country's perception of migrants would be any different if the migrants shared the same religious affiliation, race, or a similar culture, with the citizens of a certain European country. The answer can be found in several studies, starting with the one conducted in Croatia by Bulat during the most severe refugee crisis triggered by the Croatian War of Independence. While the Croatian citizens mostly expressed positive attitudes toward Croatian migrants from Bosnia and Herzegovina, they expressed a significantly greater social distance toward Bosniaks, who were Muslims. Although the Croatian citizens could relate to Bosniak refugees in terms of the defense against the war aggression, language, and race, they were still not ready for the same level of coexistence as was the case with Croatian refugees from Bosnia. Results also showed that the Croatian citizens felt highly uneasy about the immigration of migrants 
of the Islamic religion, mostly due to the "danger to Croatia from the spreading of Islamic culture and religion" (Bulat 158). Data collected by the social distance scale in the survey questionnaire showed similar results concerning different behaviors the participants engaged in when Croatian or Islamic-Bosniak migrants were in question. The results showed that only $5 \%$ of Croatian citizens would marry a Bosniak refugee, $21 \%$ of them would be friends with them, while as many as $60 \%$ of Bosniaks stated that they would be friends with Croatian refugees. $25 \%$ of respondents would prohibit the relocation of Islamic refugees to Croatia, while only $1 \%$ would prohibit the relocation of Croatian refugees (Bulat 158-63).

A similar survey was conducted in Germany by Gerhards, as part of "The Barometer of Public Opinion on Refugees" project. The main goal of the project was to examine the German public perception of migrants in Germany and Europe in general. First, the majority of participants (74\% of them) observed "the effects of the influx of refugees as negative and are of the opinion that this immigration brings more risks than opportunities in its wake" (Gerhards et al. 246). However, the results become more complex with the introduction of different categories of culture, origin, and religion, that migrants belong to. Thus, three-quarters of participants approve the acceptance of migrants who are Christians, whereas a significantly smaller number of participants agreed to the right of the acceptance of national minorities, homosexuals, and individuals of the Islamic religion. The authors concluded that the different results concerning the religion category are especially interesting and could be explained in the context of the fear of violating German culture and its fundamental values where the threat to the culture and value system is "especially attributed to Islamic refugees" (Gerhards et al. 245). Therefore, we can conclude that the othering of a particular group within a society is caused by the fear that the majority population (domicile society) might be othered in the future, in this case, in the context of existing cultural values.

Another study conducted in Germany indicates many adult Germans support anti-immigrant emotions and denial of different rights to migrants (Raijman et al. 384). The reason for this lies in the perception of migrants as a threat to domicile society on several levels. Firstly, the members of the domicile society believe migrants could take over job opportunities due to their increased number. Secondly, the members of the domicile society are concerned with the potential inability to find adequate accommodation, again due to the increased number of migrants who need 
accommodation too, as well as the impact migrants might have on the well-being and social order in the country (Raijman et al. 387). Therefore, the authors conclude that "migrants are considered as outsiders in the economic, social, and political spheres ..., as many Germans are resistant to accept foreigners as equal members in their societies" (388).

Similarly, in the perception of European citizens, we can observe social distance derived from ethnicity and religion in the context of the last refugee crisis, where most migrants were Muslim and originally from the Middle East (Wike et al. 23). The data collected through the research survey in 2016, concerning the migrants who migrated to Europe in the last refugee crisis, show that, in 8 out of 10 European countries, $50 \%$ or more citizens that participated in the research believe that migrants "increase the likelihood of terrorism in their country" (Wike et al. 3). Other results show that in 9 out of 10 countries half or more citizens believe that Muslim migrants want to distance themselves from the rest of the society to avoid assimilation in the country of destination (Wike et al. 5). It has to be emphasized that a particular public opinion does not necessarily have to be proportional to a specific number of migrants. Therefore, the demographic structure does not play a role in particular behaviors or perceptions that follow othering. For example, results show that $73 \%$ of participants in Poland perceive migrants as a major threat, while the country has had a few thousand applications for asylum in 2015 . On the other hand, only $31 \%$ of participants in Germany perceive migrants as a threat, although the country has had a few hundreds of thousands of asylum applications (Wike et al. 29).

The mentioned results and interpretations are directly connected to Wimmer's theory of xenophobia and racism. The author contests the thesis that the categories of xenophobia and racism "stem from an intensive rivalry between migrant and indigenous groups; jobs and cheap housing are especially scarce in times of economic crisis, and from the perspective of established inhabitants the migrants compete for residential space and working opportunities" (19). In the 1970s, some European countries introduced quotas that regulated employment rates of migrants or "non-national others," according to Wimmer's term, as a result of such reaction of the domicile population. According to the author, the fear of the domicile population in European countries toward the possible domination of the migrants, in the context of the economy and the quality of life, can also be observed since the first wave of massive migration in the 1880 s, when the 
governments of certain countries directly emphasized there was a large number of foreigners in their societies (Wimmer 19-20). In the 1960s, Italian migrants in Switzerland, especially those uneducated and poor, were seen as a direct threat to the state and government. They were seen as "others" who have completely different attitudes toward society and the power of the country to which they have immigrated. Despite that, they have managed to integrate, same as we see in the example of the Irish migrants in the UK (Wimmer 23). By analyzing various theories and research, Wimmer re-examines the main thesis and explains that from the perspective of the dominant society, migrants, in general, represent a threat, but racism and xenophobia occur only when it comes to non-white migrants. In modern European societies, this category can be analyzed in the context of Islamic migrants stereotyped as "fundamentalists" (Wimmer 30). Wimmer supports his thesis on the domicile population's fear of the establishment of migrant domination with various theories and research; however, the results show significantly fewer conflicts toward white migrants. Therefore, it is evident once again that the perception of threat and fear of taking over work opportunities is not the main reason for othering migrants, but the question of differences according to a certain category, in this case - race. In other words, migrants as a general category represent others, but, when it comes to migrants from developing countries who are significantly different from the domicile population in a certain category, the whole context becomes even more complex. In the following quote, we can find an explanation that illustrates the process of othering by providing a lens through which the domicile societies view migrants:

... besides this, cultural incompatibility, the low educational qualifications, and professional experience are also blamed for the new immigrants' inability to integrate into the class structure of the host society and therefore finally finding themselves in a ghettoized and marginalized subproletariat. (Wimmer 22)

According to authors who advocate this thesis, pushing migrants to the margins due to these insufficiencies results in a negative reaction of the domicile population in the reality, which is manifested in various xenophobic behaviors and rejection of the migrant population, as explained by Blumer. Blumer states that actions toward the group that is being othered in the society rise from specific emotions, attitudes, and the existence of certain public discourse. According to the author, from the feeling that the dominant group possesses an inalienable right to certain privileges 
or positions in society arises the idea of the right to certain work positions or occupations that the group that is being othered should not participate in (Blumer 4).

Wimmer also confirms the thesis that, most often, the domination and social exclusion are established on the immigration policies discourse and the representation of "ethnic others" in a specific way by the media, which, consequently, spreads into the public discourse domain. This is always fertile ground for the many manifestations of racism and xenophobia (Wimmer 25-26). Also, he describes that throughout the history of migration, migrants from developing countries have often been referred to as "colored" or "black," whereas migrants from other countries have been referred to simply as "migrants." Thus, it turned out that "migrants" managed to find a job relatively quickly after their immigration and even achieved success in their social and work positions; however, the members of the first-mentioned category of migrants were at the unskilled labor positions for decades after they immigrated, even though, according to official comparative data, they were often better-educated at the time (Wimmer 24).

According to Wimmer, "concepts of cultural distinctiveness, inability to assimilate and unbridgeable cultural difference form the basic elements of a concept of 'otherness' which helps to exclude immigrants from the core social group and to establish domination over them" (25).

On the other hand, othering that manifests through racist and xenophobic behaviors can be associated with the purpose of deeper confirmation of the "national self" and belonging to a certain group (Wimmer 27). The othering is, in this case, more linked to the self and one's own need for belonging than to the exclusion of migrants from society. This theory can be further explained by Tajfel's experiment in intergroup discrimination. According to Tajfel, this concept is present in all modern societies, often because of the aforementioned elements, such as economic competitiveness and positioning oneself in the best possible social position. The elements of discrimination are manifested in stereotypes, prejudices, various forms of discriminatory behavior, and division within groups or society as a whole. Therefore, Tajfel wanted to explore the reasons for their existence (96). According to Tajfel, this type of behavior, generated by the "Us and Them" division in society, is significant because: 
economic or social competition can lead to discriminatory behavior; that behavior can then in several ways create attitudes of prejudice; those attitudes can, in turn, lead new forms of discriminatory behavior that create new economic or social disparities, and so the vicious circle is continued. (96)

In his research, Tajfel examines this division and marks its participants as "ingroups" and "outgroups" (98). Tajfel's basic premise, confirmed by the experiment, is that in situations that are relevant, in terms of intergroup relations or the interest of one or both groups, people tend to identify more deeply with their own group and discriminate against another group, outgroup, or others. Tajfel also predicted that discriminatory behavior occurred even when there was no particular interest in groups, even when there were no overtly established attitudes toward the other group nor any prescribed norms of behavior, still, the discriminatory behavior was directed toward another group before defining the stereotypes or prejudices that guide the behavior. In the stated hypotheses, it is evident that the most important element in these relations is that they care about others, while the reasons for othering are less important. The research shows the strength of the division between the groups and the process of othering, which does not have to necessarily be based on previous discrimination, prejudice, stereotype, or conflict of any kind, but only on a sense of belonging to one's group, while on the other spectrum stand - "others." Therefore, an answer to the reason for othering behavior might lie in this research. Certain groups in the society necessarily fall under the process of othering, partly to identify more strongly with their group and partly because of the fear of others.

\section{Symbolic Representations of Othering: Place, Picture, and Boundaries}

The process of migrant othering can also be observed on a symbolic level, which is often harder to recognize because it is not always as direct as the behavioral one. However, the symbolical level, in which certain elements of othering, especially contemporary ones, are manifested in the context of migration, is ubiquitous. Nevertheless, it often cannot be observed separately from the lingual and behavioral category, therefore, it is necessary to analyze it in direct connection with the latter. 
The factor that directly indicates the importance of the symbolic category is analyzed through the specific elements of the place or location where migrants are situated. First, I observe the importance of the location where migrants are situated in relation to the domicile population, then emphasize the differences in the context of place between several categories of migrants, and finally provide empirical data as proof that we can indeed observe othering through the aforementioned three categories.

After migration, the migrant population in many countries is usually located on the outskirts of the cities. We can observe that strategy in the example of Croatia through the last great migration to Europe. Since September 2015, after Hungary and Serbia closed their borders for migrants, people were primarily entering Croatia to get to Slovenia and continue their journey to other European countries. Thus, migrants were mainly located in Croatia on the city margins of Zagreb or Sisak and along highways, such as in the reception center Ježevo (Hameršak and Pleše 16). Although there might be a practical reason for such accommodation, this strategy might result in the ghettoization of migrants, which creates an obstacle to full integration into society. When the transit center for refugees in Opatovac, Slavonia, opened, it was a practical solution for accommodating a larger number of people, yet, on a symbolic level, it indicated a locational shift to the margins, away from cities and the local community. Surely, one of the reasons for the location of the centers is the greater control possibilities and supervision of migrants. Furthermore, at the beginning of the crisis several times a day, refugees that finished the registration process in Opatovac were arriving at the Ključ Brdovečki station from Tovarnik, after which they walked for about 20 minutes to the Slovenian border accompanied by the special police force where many of the refugees had to spend several nights outside in the cold (Hameršak and Pleše 18). After the decision-making process between some Balkan countries, the refugees would no longer be waiting in front of the borders but be transported to other countries by train. Although new decisions somewhat improved the transit process, the authors recognized that the corridor was "completely isolated" from the rest of the territory, legal system, and other citizens (Hameršak and Pleše 19). The authors Hameršak and Pleše stated that:

by striving to establish control over migration, the country was in some way accepting the patterns of migration of the so-called "irregular migrants." The refugees were under police control upon 
entering or departing from the country almost as if these were the so-called illegal, secret transitions, and the paths they took were not permanent, that is, they depended on many factors, from the weather conditions to sudden short-term and long-term evaluations, decisions, and agreements of different actors, countries, police, etc ${ }^{[4]}(18-19)$

Studies mentioned in the previous chapter point to the different treatment provided to different migrant groups. When it comes to place, it can be explained by restrictive immigration and asylum policies within the concept of "Fortress of Europe ${ }^{[5]}$ " which emphasizes border security in the South and East as its primary policy strategy (Župarić-lljić and Gregurović 43). Protecting Europe from others coming from countries outside of the "old continent" is a practice followed by many countries in modern migration. We can analyze it by comparing the process of accepting and accommodating migrants from the former Yugoslavia who moved to Germany during the war and, on the other hand, migrants in contemporary migration.

In Germany, migrants from Croatia and Slovenia were issued work licenses and therefore did not have to seek asylum because they managed to support their families and live safely (ZlatkovićWinter 134). On the other hand, according to the aforementioned European practice, migrants in the last migration were located outside the cities, meaning there was no contact between them and the domicile population while waiting for a decision on protection, and sometimes even after they had obtained protection in a given country. One possible explanation for this acceptance strategy might be the number of migrants, which resulted in the need for Europe to preserve security in its countries. However, following the previous wave of immigration to Croatia, during the Croatian War of Independence, a large number of migrants was registered as well but were taken care of in the very center of Zagreb, in the Hotel InterContinental, around the mosque in Zagreb city center or the, then luxuriously decorated, tourist resort Hotel Marina in Červar Porat. At that time, as well as in modern migration flows, many migrants have fled war or poor living conditions, but they were not located far from the rest of the population nor strictly controlled (Zlatković-Winter 134). Comparing these two migration processes to Croatia, it is possible to conclude that the main factor in current migration is that Europe perceives the coming individuals as some other migrants who are unknown to European society by several categories - language, religion, and culture. The main reason for emphasizing the place based on location determinism is that, because of it, the migrant 
population remained distant from the domicile population and everyday social life from the very beginning of the last migration to Europe. By placing foreign nationals on the margins of cities, they are referred to as "others," those who are not part of "our" society. The result of this frequent practice is that the migrant population becomes, and also remains, unknown to and distant from the rest of the society.

The next level of the symbolic category is the representation of migrants through images and pictures. Many studies primarily focus on this level of othering and its importance in the media. Images and pictures are important in this context, since according to Amores "the symbolic and expressive weight of an image is much greater than any written text, especially when it comes to photographs" (148). Thus, the results of photographs found in media coverage indicate that the migrant population is most often depicted in refugee camps, urban areas, at borders, or on ships (Amores et al. 154). The photos show migrants themselves, and when it comes to other individuals besides migrants, it is most often the police or some other security services (13.6\%) or a smaller percentage of volunteers (9\%) (154). Very rarely, or never, have they been portrayed as a part of the society or in the processes of integration into the society to which they had migrated. One of the reasons may be, as mentioned before, that the domicile society recognizes migrants from the Middle East as the unknown category according to several key elements - language, culture, or religion. The importance of the symbolic representation from which the metatext of the othering can be observed is also analyzed by many authors when it comes to migrants in Denmark. Thus, Jensen believes that the Danish public discourse related to integration, migration, and national minorities is somewhat specific as far as national minorities are concerned, especially young men (63). According to Jensen, one can recognize othering toward mentioned groups in society that arises from differences based on race, nationality, and sex (67). Thereby, the presence of others in Danish society is particularly problematic, with an emphasis on "young ethnic minority men, in particular, that have been subject to pathologization by discourses which link ethnic minority backgrounds to crime and/or problematic and aggressive sexuality," most often belonging to the migrant population of the Islamic religion (Jensen 63). McLaren observes the following idea as a clear manifestation of the othering - "the non-white and non-Danish is then equated with the savage, uncontrolled and deviant as opposed to orderly and civilized Danishness" (60). Also, in 
most media coverage studies (Downing and Husband), migrants are analyzed homogeneously as the same group without special attention to potential differences in media coverage depending on the nationality.

The last category refers to symbolic boundaries and represents the consequence of the place and picture as the main othering elements. Boundaries most often arise between the dominant population and migrants, while in multicultural societies, there are also symbolic boundaries that separate the domicile society from immigrants and national minorities, and migrants among themselves depending on their origin and culture. Apart from considering boundaries in a territorial and legal context, they can also have symbolic connotations and consequences. Symbolic boundaries are defined, according to Bail, as the separation of groups in society based on different characteristics, such as the differences in origin, religion, mother tongue, or culture (38). However, symbolic boundaries can also be defined concerning territorial ones. For example, citizenship assumes the possibility of residence within the borders (or territorial boundaries) of a certain country in the long run, as well as many rights that come with it. However, it also represents a symbolic boundary toward those individuals who are not adequate and do not meet the conditions required by the state, which is why they are excluded from this category (Bail 39). According to Bail, policies and strategies related to citizenship and the rights of foreign nationals who have immigrated to Europe directly point to ideologies of inclusion or exclusion of the migrant population, depending on the country. During the period of immigration of German citizens from East Germany to West Germany and frequent immigration of migrants of non-German origin, such as Turks, there was valid legislation prescribing the right to grant German nationality and related rights. Thus, a rather simple statement explained that any person who declares him/herself to be "ethnically German" will be considered a German (Raijman et al. 380). At first, it might be considered an easy way to become a German, with the obligation of knowing the German language and culture. However, the metatext on the symbolical level, contained in the regulation, points directly to the alienation of migrants coming to Germany, who need to publicly and legally renounce their identity to become Germans and earn certain rights that come along with it. There is a similar situation found in France, where only three categories in society are recognized. The first category is "French by birth," the second is "French by naturalization," and the third is "foreign" (Kastoryano 
86). As Kastoryano stated "in France the national and ethnic origin of citizens does not appear in official documents, and, consequently, has no legal or statistical validity. The code of Nationality sets up statistical categories that exclude questions of "origin" once French nationality is obtained" (Kastoryano 87).

The authors focusing on the category of migrants and symbolic boundaries in Europe, as well as on the process of othering of certain groups in society, point out the fact that, throughout the history of Europe, there was an emphasis on the categorization according to race within society. However, after World War II until today, Europe has been increasingly distanced from the racial category and moving toward the category of religion, which is why today, in the context of othering, the emphasis is placed on individuals of the Islamic religion (Bail 44). Although over the years, both racism and, in recent history islamophobia, have become politically incorrect topics, the latest migration to Europe shows that the latter still largely exists in Europe among many societies. According to Bail, although in countries where racist and Islamophobic attitudes in the society have not been recorded as intensively as in Germany or France, and their strategies do not go in the direction of othering based on these two categories, the process of othering is nevertheless present. Therefore, in the Southern European countries, the symbolic boundary between immigrants and the domicile population is based on the economic context precisely because they see others through the prism of the potential invasion of the job market. For example, Greeks most frequently show attitudes toward immigrants as the main perpetrators for their high unemployment rate compared to other societies in Europe. When it comes to Eastern Europe, although it statistically shows the lowest percentage of immigrants through the whole history until today, they express the highest level of racism compared to other countries, while other important symbolic boundaries emerge based on categories of religion, culture, and language (Bail 46).

The studies that include media coverage and general public opinion based on the symbolic boundaries are extremely important and will therefore be analyzed in the next chapter. However, the basic conclusion of this chapter is that othering inevitably takes place throughout Europe on several levels, which can be manifested by symbolic categories of boundaries between societies and individuals. 


\section{The Power of Language as an Element of Othering}

In the category of language, the role of the media and their portrayal of the migrant population is inevitable, this time in the context of using specific terminology and titles. Thus, the media were the main creators of the mainstream terminology about migration, especially during the last immigration to Europe. This is important because the terminology used both by experts and journalists in the media, especially in news programs, is widely used by the general public. According to Toğral Koca, "the speech acts of certain actors like politicians, the media, and the public, migration can be designed as an 'existential threat' to societal security/identity" (Toğral Koca 58).

In this chapter, I argue the important role of media in the context of opinion-making and provide empirical data from studies that examine the media coverage of migrants in the context of terminology used.

Most media in European countries, with an emphasis on television and the Internet, portrayed the migrant population predominantly in two ways at the beginning of the last European refugee crisis - as a threat on the one hand and as passive victims on the other (Figenschou et al. 66). Nonetheless, in the first year of the refugee crisis, the media have often been focused on the representation that indicates migrants as a possible threat to European society. These representations are extremely important if we consider the fact that, for the citizens of many countries which are not traditionally immigrant, such as Croatia, the main source of information and the only (indirect) contact with migrants is through the television. Many types of research show that television is considered more objective than other media and is considered to provide more accurate information, which is why it is perceived as the medium with the greatest influence on opinion-making (Legčević et al. 487-90). Therefore, the way migrants are represented in the media and the specific terminology the media uses are of crucial importance since they have a leading role in forming public opinion on a particular topic or a certain category of people. According to Grubiša, the media had an important role in creating "Us and Them" divisions in society, by showing the images of chaos, disorder, crowd trying to cross European borders, at the very beginning of the refugee crisis (155). The news often showed individuals trying to knock down 
fences placed by police, while the television reporters used terms such as "flood" or "river of refugees." Thus, the following article titles are found on Croatia's most-read portals at the very beginning of the migration: "Investigative prison for asylum seekers - suspected of raping a girl in Zagreb," "Where can the refugees be found in Croatia?" "Refugees, give us your phones so we could find out who you really are," "Refugee scandal shakes Germany," "Neighbors send thousands of people, raise the wire, close borders," "There was chaos, but then buses arrived and transferred them to the border," "Border police find truck overloaded with refugees: Attempt to smuggle into Western Europe, among the total of 91 captured, 29 children found. ${ }^{[6]}$ Using such terminology and titles, migrants are not only depersonalized and portrayed as an exclusively homogeneous group of people but also as a threat to the societies to which they migrate (Grubiša 149). In other countries, we can observe similar examples. According to Alexander, in the UK, the media often use terminology such as "gang" or "group" for migrants (77), emphasizing their gathering in city centers, as if it is a warning to the rest of the population to avoid those places. In certain media, especially television, there are several terms often used by TV hosts or experts, after which they have been transferred to the mainstream language. Terminology analysis is important because the frequent emphasis on terms such as "national protection," "border security," or "threat" in public space forms the idea that migrants are a real threat from which the domicile population should be protected (Grubiša 156). One of the most commonly used terms in the media that refers to Europe's position on migrant arrivals is the terminology of the process of immigration to Europe entitled „refugee crisis." The question can be asked, the refugee crisis for whom? The answer is clear - it is a crisis for Europe, for all European countries and societies. The basic terms mentioned in the media in 2015 became commonly used in everyday speech, indicate the absence of order, panic, social pathology, and insecurity, in short - a period of crisis for Europe. That assumes Europe's position, indicative of the state of general crisis and insecurity caused by the large number of people who are "foreign," "other," and "potentially dangerous."

Numerous studies indicate that the media terminology and language are critically important regarding the inclusion or exclusion of the migrant population in society and the general idea of the society in terms of integration. The authors Figenschou et al. studied the influence of the Islamic migrants' representations in the Norwegian media on the attitudes of the domicile society on 
immigration issues and attitudes toward integration. The research showed that the participants became aware of this issue and began to perceive it as very important for their society as a direct result of specific media coverage (Figenschou et al. 75-76). Moreover, a similar study conducted in Belgium showed there was a significant negative correlation between the use of television owned by private corporate media and attitudes toward the migrant population and a positive one between attitudes toward the migrant population and trusting information broadcasted by television and radio (De Coninck et al. 17). The results also showed a correlation between specific attitudes and consulting two different kinds of newspaper - quality newspaper and popular newspaper. There was a positive correlation between the informative use of quality newspapers and positive attitudes toward immigrants, whereas using popular newspapers and trusting their sensationalist news showed a "negative effect on attitudes toward immigrants and refugees" (De Coninck et al. 18). In the case of television, the results were similar to those in Croatian research mentioned earlier, where a significant positive correlation was found between the informing on national television and the formation of attitudes about immigrants (De Coninck et al. 18). To sum up, the authors conclude that the results indicate the importance of certain types of television and newspaper in the process of forming specific attitudes toward immigrants (De Coninck et al. 25).

Finally, a specific way of migrant representation and using certain terminology in the media and public space does not only result in shaping attitudes but, according to some authors, also to social actions in real life. In 1958, Blumer analyzed the social perception of race and later racism. His basic thesis was that racism is always necessarily collective, present at the level of a group or a society, rather than individual, while creating racial differences. Although this thesis might fall into a symbolic or behavioral category, since we are familiar with the behavior affected by racist attitudes throughout history, Blumer's thesis fits better into this very last section devoted to language. According to the author, racism and race division in societies are created in the media space using a specific narrative, where "individuals who are accepted as spokesmen of a racial group characterize publicly another racial group. To characterize another racial group is, by opposition to define one's own group" (Blumer 4). Blumer puts forward the idea that placing one group against another or defining one's belonging and identity necessarily in opposition to another forms the basis for the formation of racially conditioned prejudices. Such social conditions that represent a 
constant in the public space and media give rise to certain emotions that might, in some cases, generate real action. Those emotions are sorted into several categories, according to Blumer. First, in the dominant group, which in the context of this paper represents the domicile population in a country that accepts migrants, feelings of superiority over another group may form. Blumer explained it as "a feeling that the subordinate race is intrinsically different and alien" (4). Second, there may be a feeling of having the exclusive right to certain privileges and, finally, the fear of possible violation of that order by other groups or subordinating the dominant group in society by others or in the context of this article - migrants. These feelings are important for the process of othering because they directly put migrants "below" and "beyond," excluding them from the rest of society (Blumer 4). Blumer's categories are not necessarily expressed only in behavior but in the usage of a language as well. It can be observed through stories, messages, gossip, using specific words, news, or anecdotes, where the words with a specific meaning have the most important role. Blumer especially referred to the speech, newspaper titles in the press, the specific terminology, and words used by the powerful representatives of the dominant group in public because they reach the masses they represent. This continues to intensify the identification with the dominant group and division of "Us" and "Them." I conclude this chapter with Blumer's quote that rounds out the central premise of the chapter: "What goes on in this public arena attracts the attention of large numbers of the dominant group and is felt as the voice and action of the group as such" (Blumer $6)$.

\section{Conclusion}

In this paper, I have tried to show the premise stated at the beginning, which refers to migrants as othered individuals, perceived by the domicile society as foreigners or others. To do so, I have formed three categories of the othering process in the context of migration.

The behavioral-perceptive category refers to the reaction of the accepting society to the migrant population through social practices on the one hand and attitudes and perceptions on the other. A securitarian approach to migrant acceptance has proven to be crucial in Europe, during which the othering process can be easily recognized through everyday behavior toward the migrant population. The research used in the paper indicates mostly negative attitudes of certain European 
societies toward migrants, which, according to theorists, should not be observed only in attitudes but in behavior in everyday life as well. This can be observed in the level of acceptance of migrants, where certain migrants are more welcome, and others are on the margins of everyday social life. The second category is a symbolic one. The symbolic category of othering is particularly complex, as it is the most difficult to detect. In this category, the most important factors are the location of migrants that is often far from the domicile population, the representation of migrants through the media image, and the symbolic boundaries. The symbolic category is necessarily intertwined with the other two categories since it can be observed both in behavior and language. This category is also the most dangerous one since it is difficult to recognize and is, as a result, often overlooked without thinking about its meaning and consequences. Finally, the category of language follows the previous one because its foundation lies in the importance and power of the media, including the experts and the other opinion-makers in the media space, with regard to shaping public opinion and attitudes in general. Thus, it has been shown that the specific terminology choice is crucial in generating othering toward migrants because it is present in everyday public use.

It has been demonstrated that the othering is always necessarily present and will remain present in the future, despite the demographic structure of the societies or the specific number of "others" in a certain society, as was explained in Wike's research. Finally, the root of othering, in the case of migrations, especially modern ones, can be recognized in many ways. It can result from mere ignorance of a different culture and the individuals belonging to it, as well as from the lack of experience with immigration in general, or direct perception of others as a threat.

\section{Works Cited}

Alexander, Claire E. The Asian Gang: Ethnicity, Identity, Masculinity. Berg Publishers, 2000.

Amores, Javier J., et al. "Visual Frames of Migrants and Refugees in the Main Western Media." Economics and Sociology, vol. 12, no. 3, 2019, pp. 147-61.

Bail, Christopher A. "The Configuration of Symbolic Boundaries against Immigrants in Europe." American Sociological Review, vol. 73, no. 1, 2008, pp. 37-59. 
Blumer, Herbert. "Race Prejudice as a Sense of Group Position." The Pacific Sociological Review, vol. 1, no. 1, 1958, pp. 3-7.

Bulat, Nenad. "Dimenzije stereotipova i predrasuda u odnosu na raseljene osobe i izbjeglice iz Bosne i Hercegovine." Migracijske i etničke teme, vol.11, no. 2, 1995, pp. 151-71.

Buzan, Barry, and Ole Wæver. "Macrosecuritization and Security Constellations: Reconsidering Scale in Securitization Theory." Review of International Studies, vol. 35, no. 2, 2009, pp. 253-76.

Castles, Stephen, et al. The Age of Migration: International Population Movements in the Modern World. Macmillan Press, 2003.

De Coninck, David, et al. "The Relationship between Media Use and Public Opinion on Immigrants and Refugees: A Belgian Perspective." Communications, vol. 43, no. 3, 2018, pp. 403-25.

Downing, John, and Charles Husband. Representing 'Race': Racisms, Ethnicity and Media. Sage Publications, 2005.

Figenschou, Tine, et al. "The Moral Police: Agenda-setting and Framing Effects of a New(s) Concept of Immigration." Nordicom Review, vol. 36, no. 1, 2015, pp. 65-78.

Gerhards, Jürgen, et al. "German Public Opinion on Admitting Refugees." DIW Economic Bulletin, vol. 6 , no. 21,2016 , pp. 243-49.

Grubiša, Iva. “'Us and Them': Approaching the Refugee Other? Cultural Anthropological Rethinking of the Fieldwork Experience in Slavonia." Narodna umjetnost: hrvatski časopis za etnologiju i folkloristiku, vol. 54, no.1, 2017, pp. 147-68.

Hameršak, Marijana, and Iva Pleše. "Zarobljeni u kretanju: o hrvatskoj dionici balkanskog koridora." Kamp, koridor, granica: studije izbjeglištva u suvremenom hrvatskom kontekstu, edited by Emina Bužinkić et al., Institut za etnologiju i folkloristiku, 2017.

Jensen, Sune Quotrup. “Othering, Identity Formation and Agency.” Qualitative Studies, vol. 2, no. 2, 2011, pp. 63-78.

Kastoryano, Riva. "Codes of Otherness." Social Research, vol. 77, no. 1, 2010, pp. 79-100. 
King, Russell. "Theories and Typologies of Migration: An Overview and a Primer." Willy Brandt Series of Working Papers in International Migration and Ethnic Relations, vol. 12, no. 3, 2012, pp. $3-43$.

Legčević, Jelena, et al. "Uloga povjerenja u medije u informiranju i kreiranju mišljenja u javnosti." Kvaliteta i društvena odgovornost, 2012, pp. 487-99.

McLaren, Peter. "White Terror, and Oppositional Agency." Multiculturalism: A Critical Reader, edited by D. T. Goldberg, Wiley, 1994.

Pozniak, Romana, and Duško Petrović. "Tražitelji azila kao prijetnja." Studia ethnologica Croatica, vol. 26 , no. 1,2014 , pp. 47-72.

Raijman, Rebeca, et al. "Do Foreigners Deserve Rights? Determinants of Public Views towards Foreigners in Germany and Israel." European Sociological Review, vol. 19, no. 4, 2003, pp. 37992.

Said, Edward W. Orientalism. Penguin, 1977.

Simmel, Georg. The Stranger. University of Chicago Press, 1971.

Tajfel, Henri. "Experiments in Intergroup Discrimination." Scientific American, vol. 223, no. 5, 1970, pp. 96-103.

Toğral Koca, Burcu. "Syrian Refugees in Turkey: From 'Guests' to 'Enemies?'” New Perspectives on Turkey, vol. 54, 2016, pp. 55-75.

Wike, Richard, et al. Europeans Fear Wave of Refugees Will Mean More Terrorism, Fewer Jobs. Pew Research Center, 2016.

Wimmer, Andreas. "Explaining Xenophobia and Racism: A Critical Review of Current Research Approaches." Ethnic and Racial Studies, vol. 20, no. 1, 1997, pp. 17-41.

Vujadinović, Dragica. “O europskom identitetu.” Synthesis philosophica, vol. 26, no. 1, 2011, pp. 117-32.

Zakon o međunarodnoj i privremenoj zaštiti. Narodne Novine, 2018. www.zakon.hr/z/798/Zakon-ome\%C4\%91unarodnoj-i-privremenoj-za\%C5\%A1titi. Accessed Jan. 2019. 
Zlatković Winter, Jelena. "Suvremena migracijska kretanja u Europi.” Migracijske i etničke teme, vol. 20 , no. $2-3,2004$, pp. 161-70.

Župarić-Iljić, Drago, and Margareta Gregurović. "Stavovi studenata prema tražiteljima azila u Republici Hrvatskoj." Društvena istraživanja: časopis za opća društvena pitanja, vol. 22, no. 1, 2013, pp. 41-62. 
[1] This paper has been supported by the Catholic University of Croatia under the project "Otherness as the Social and Cultural Determinant of the Croatian Past," no. HKS-2017-7 [2] In the paper, I use the general term "migrants" or "migrant population" to refer to any individual who may have emigrated from his country of origin for any of the various reasons, be it war destruction or job seeking. Although in the typology of migration we can differentiate forced from voluntary migration, as well as distinguish refugees from voluntary, economic migrants, the term "migrants" covers all abovementioned individuals, regardless of the reason for their migration (King 8).

[3] The term refers to individuals situated at the migrant centers who wait for a decision on obtaining or refusing international or temporary protection or asylum in a country (in this case Croatia). According to the Law on International and Temporary Protection for the year 2018, those individuals who have been granted refugee status based on the determined fear of persecution due to an individual's race, religion, or nationality have a right to a certificate of asylum, while those who do not fulfill criteria for asylum, but there is strong suspicion their return to their country of origin might result in a violation of justice have a right to a certificate of subsidiary protection. Violation of justice can refer to the threat of the death penalty, torture, or any other inhuman practice (Zakon 8).

[4] The original text is translated from Croatian by the author of this paper.

[5] "Fortress of Europe" represents a term that refers to the idea of strong borders, the economy, and the homogeneity of European society in the context of immigration, which was formed in the 1980s, but was very important in the 1990s. In addition, in the 2000s, the Schengen area was created, which makes Europe a closed „fortress" concerning the rest of the world and immigrants coming to European countries (Vujadinović 124).

[6] The titles were gathered using a qualitative method of media coverage, with the selected titles exclusively related to migrants. This paper does not list all the titles gathered by the analysis. The articles were published on the Internet portals of the following newspapers in the period from 2015 to 2017: Večernji list, Poslovni dnevnik, Jutarnji list, and HRT Dnevnik. 


\section{(c) (i) (9)}

Creative Commons Attribution-NonCommercial-NoDerivatives 4.0 International License 